\title{
Townships as Crime 'Hot-Spot' Areas in Cape Town: Perceived Root Causes of Crime in Site B, Khayelitsha
}

\author{
Jean-Claude Manaliyo \\ North West University, South Africa \\ Email:25842927@nwu.ac.za
}

\section{Doi:10.5901/mjss.2014.v5n8p596}

\section{Abstract}

Crime in South Africa continues to devastate lives and prosperities of many people despite significant strides the country made to combat crime soon after the fall of apartheid in 1994. South Africa has implemented different crime prevention strategies but the crime situation in the country is unabated, particularly in poor communities and townships. The aim of this study is to investigate and understand root causes of high crime rates in Cape Town townships using Site B in Khayelitsha as a case study. The study used qualitative method in which purposing sampling approach was employed to select participants of the study, and data was collected by means of in-depth face-to-face interviews. Findings of this study revealed that poverty and high unemployment rate are perceived as the major factors responsible for high crime rates in Site $B$ community. Other identified determinants of crime include ineffective criminal justice system, lack of proper parental guidance, and bad social role models.

Keywords: Causes of crime, parental guidance, bad social role model, ineffective criminal justice system, township

\section{Introduction}

South Africa has made impressive progress in consolidating democracy and fostering non-racial society after the demise of apartheid in 1994. The country is now seen as an exemplary democratic country on the African continent. However, crime remains among the top challenges post-apartheid South Africa has to address urgently to ensure every South African lives dignified life (Demombynes \& Özler, 2005; Burger, 2007; de Velliers \& Nel, 2009). The crime situation in the country is unbearable despite some claims from the South African Police Service (SAPS) that crime rates are declining (Institute of Security Studies, 2012; Cunliffe-Jones, 2013; Republic of South Africa, 2013). The majority of South Africans are still exposed to high levels of crime. Some of the South Africans have already been crime victims while others live in fear of being crime victims. A study carried out in 2011 in different provinces in the country shows that only $37 \%$ of the surveyed households believed that both violence and non-violence crime had decline in their areas of residence between 2009 and 2011 (Statistics South Africa, 2012).

Crime and fear of crime are rated by business owners as major challenges business faces in South Africa (RSA, 2008). This view that South Africa is unsafe adversely impacts on foreign investment in the country. Some foreign investors believe that South Africa is insecure environment to invest (Stone, 2006). On the flipside, crime costs the South African government a substantial amount annually which is spent on administration of the criminal justice system and crime prevention programmes.

Some of the national crime prevention policies implemented in South Africa since the demise of apartheid in 1994 include the reconstruction and development programme (RDP) implemented in 1994. The policy intends to reduce and prevent crime by addressing poverty and socio-economic inequalities and other factors that force individuals into criminal activities (Brown, 2001). In 1996, the government implemented the national crime prevention strategy (NCPS) (RSA, 1996) which followed by the White Paper on Safety and Security adopted only two years after the implementation of the NCPS (RSA, 1998). To respond to crime rates which were escalating in the country, in 2002 the South African Police Service (SAPS) developed its own in-house national crime combating strategy (NCCS) (SAPS, 2002). Given the current crime situation in the country, one may argue that the policies have failed to fight crime effectively. The government concentrated its efforts and resources on crime reduction without addressing factors that force individuals to pursue illegitimate activities (Manaliyo, 2012).

The prevalence of high crime rates in South Africa however, is not a new phenomenon. High crime rates were very high even the time of political instability during the apartheid (Shaw, 1997; Shaw, 2002; de Wet, 2003; Møller, 2005) but the significant increase in crime was noticed from 1980 to 1990, a decade in which anti-apartheid activities intensified in 
the country (Shaw, 1997). In 1989, South Africa recorded 10000 murder cases and the number rose to 11000 cases in 1990. Within fifteen months ended in February 1991, the South African police estimated 22000 deaths engendered by crime related to violence. In the following year, South Africa was ranked one of the countries with the highest crime rates in the world. In that year, 16067 murder cases were reported alongside 78677 robbery cases and 24360 rape cases (Winslow, 2002 cited in Ikejiaku, 2009).

The abolition of apartheid gave hope many South Africans and the international community that crime rates will noticeably decline but the crime situation in the country is still intolerable. Existing literature indicates that South Africa is among the countries with high crime rates and violence in the world (Møller, 2005; Paulse \& Lazarus, 2010; Ratele, 2010; GPI, 2013). In the 2010, South Africa was ranked by Global Peace Index (GPI) 121 out 149 countries with least peaceful societies while it was ranked 123 out of 144 countries in the previous year (Ratele, 2010). Last year in 2013, South Africa was ranked 121 out of 162 countries (GPI, 2013).

Criminal activities in South Africa are concentrated in big cities including Durban, Johannesburg, and Cape Town having highest crime rates. In fact, Cape Town is among the top cities with highest murder in the world (Gie, 2009; Berlinger, 2012; Legg, 2013). Within Cape Town, criminal activities are concentrated in poor communities and townships such as Khayelitsha, Gugulethu, Nyanga, and Mitchell's Plain. ${ }^{1}$ Khayelitsha however, tops all crime hot-spot areas in Cape Town. The township contributes significantly to murders and armed robbery in Cape Town (Kagee \& Frank, 2005; Silber \& Geffen, 2009) and is one of the most violent urban areas in South Africa (Nleya \& Thompson, 2009).

Root causes of high crime rates in South Africa's townships remain contentious among government officials, politicians, scholars, and development actors. However, existing literature consistently links high crime rates to a number of factors including apartheid regime (Palmary, 2001; Shaw, 2002, Demombynes \& Özler, 2005; Singh, 2005; Nleya \& Thompson, 2009). The regime was uninterested in fighting and preventing crime in areas occupied by black Africans as it had no policy in place on fighting and preventing crime in black African communities. The government's priority was to protect minority white people and their paraphernalia. Apartheid was spending heavily on controlling black Africans to ensure there are no uprisings against it. Police and other resources were intensely allocated in white areas so crime and violence in black African communities could not spread to white areas (Shaw, 2002).

High crime rates in South Africa are also liked to income distribution. Poverty and long-term unemployment among black Africans who were previously discriminated and marginalised from major socio-economic spheres by the apartheid government are included on list of root causes of crime in the country (Palmary, 2001; Shaw, 2002; Demombynes \& Özler, 2005; Nleya \& Thompson, 2009). Given that the majority of South Africans live in poverty (Armstrong, Lekezwa \& Siebrits, 2008), economic benefits attached to crime are seen as a factor that attracts individual poor people to commit crime. Economists argue that individuals pursue criminal activities to maximize economic benefits associated with crimes (Brown, 2001; Demombynes \& Özler, 2005).

Still on causes of crime, the role of the criminal justice system in fighting and preventing crime in South Africa is questionable. The main purpose of the criminal justice system is to fight crime and promote justice but the South African criminal justice system is perceived by many South Africans to be weak, corrupt and ineffective (Shaw, 1996; Brown, 2001; Singh, 2005). There are allegations that criminals are sometimes not arrested, or are released on bail without being prosecuted and many crime cases go undetected (Singh, 2005). Even those cases taken to court take longer to be completed (Schönteich, 1999). This caused many South Africans to lose faith in the criminal justice system especially the SAPS (Faull, 2007, Manaliyo \& Muzindutsi, 2013).

Weak parental guidance also appears on the list of crime determinants in South Africa (de Wet, 2003; Frank, 2006; Nleya \& Thompson, 2009). Parents are generally blamed for not playing their parental role in terms of guiding and preventing their children from pursuing illegitimate activities. Existing literature shows that juvenile delinquency in South Africa is very high (Palmary and Moat, 2002). A study conducted in 2002 found that $36 \%$ of all sentenced prisoners were young people, and $53 \%$ of all awaiting trial prisoners were young people under 26 years (Palmary \& Moat, 2002). In comparison with other countries, children in South Africa start committing crime while are still young (10-15 years) whilst children in other countries start committing crime at the age of 16-18 years. Committing crime has been normalised in some communities. In fact, committing crime has become a way of acquiring status (Pelser, 2008).

Some parents on the other hand, are too busy and have no time for their children because of work. Thus, parents may not be aware of crimes committed by their children. This occurs often in townships where a large proportion of children is left at home with no supervision during the day (Palmary \& Moat, 2002). Surprisingly, there are some parents and adults who use or push children into criminal activities instead of guiding and deterring then from pursuing criminal

1 Township in the South African context refers to the often underdeveloped urban living areas that were reserved by apartheid for nonwhites, principally black Africans and Coloureds (Estelle, 2003). 
activities. Children are encouraged to commit crime on commission or are shown how to commit crime, or are provided with means to commit crime (Frank, 2006).

It is event that children brought up in disorganised communities where many families are poor or broken are more likely to get involved in criminal activities (South African Council for Education, 2011) because disrupted families rarely exercise informal social control over their children (Sampson \& groves, 1989; Weijters, Scheepers \& Gerris, 2009; Manaliyo \& Muzindutsi, 2013). Indeed, children in dysfunctional families are exposed to numerous factors that may force or motivate them to pursue illegitimate activities. Such factors include: a high level of family conflict, family violence, break-up, and experience abuse and poor communication with their parents (Muhammad, 2008).

The role of drug abuse and alcohol consumption in promoting high crime rates in South Africa should not be undermined. Findings of different studies in South Africa disclosed that alcohol consumption and drug abuse contribute significantly to high crime rates in the country (Shaw \& Louw, 1997; de Wet, 2003; Newham, 2005; Nleya \& Thompson, 2009). The number of crimes committed when crime victims or assailants are under the influence of drugs or alcohol is high. In 2003 , one study uncovered that $40 \%$ of crime case victims believed that the assailants were under the influence of alcohol or drugs at the time of assault whilst one third of victims conceded to having been under the influence of alcohol and drugs at the time of assault (Omar, 2004). This was corroborated by data from the Non-Natural Mortality Surveillance System (NNMSS) of 2004 which reveals that alcohol consumption contributes significantly to crime rates in South Africa (South Africa Medical Research Centre (SAMRC) \& University of South Africa (UNISA), 2004). On the same token, crime statistics also show that the number of crimes committed under the influence of alcohol and drugs is steady increasing (SAPS, 2011).

\section{Methodology}

The research was conducted in Site B, which is one of the constituents of Khayelitsha township. Khayelitsha is the largest township in Cape Town and one of the largest townships in South Africa (University of Stellenbosch, 2011). In terms of crime, Khayelitsha tops crime hot-spot areas in Cape Town and is one of the most dangerous areas in South Africa (OECD, 2008). The selection of Site B community as a study area, was influenced by its current crime situation. The community is renowned area with high crime rates in Khayelitsha (City of Cape Town, 2009). This area is characterised by crowded and unplanned informal houses with limited access to water supplies, toilets, and streets are narrow and dirty with limited lights and others have no lights at all.

The study used qualitative method to enable the researcher to deeply understand and address the research problem. Data was collected in October 2011 from 45 participants who play different roles and have different responsibilities in Site B community. The participants included: community leaders (ward councilors and street committee leaders), community residents, and representatives of anti-crime organisations (such as Khayelitsha Development Forum (KDF), Khayelitsha Security and Safety Forum, South African National Civic Organisation (SANCO), Community Policing Forum (CPF), and the South African Police Service (SAPS)). In-depth face-to-face interviews were used to collect the data to allow the researcher to explore participants' experiences and perceptions towards crime in Site B.

The participants were selected using purposive sampling method. This method was chosen because it allows a researcher to choose participants who are assumed to possess and provide valuable information to the research question (Guarte \& Barrios, 2006). Purposive sampling method also gives a researcher the flexibility in deciding the type of information to be known and how to get the information (Bernard, 2002 cited in Tongco, 2007). By using the purposive sampling method, the researcher had the flexibility and opportunity to select participants based on their experience and quality of information on crime in Site B. Before interviews taking place, explanation regarding the objectives and purpose of the study was given to participants. The participants were informed that they could withdraw from the interviews at any stage and that the interviews will be recorded. Furthermore, the researcher assured the participants that their inputs will be treated as confidential and their identities will remain anonymous.

After collecting data, all interviews were transcribed into word-for-word transcripts which were printed out to allow the researcher to read and easily understand them. The researcher reviewed the research questions to be answered. Then each question was linked to every individual's response to identify consistencies and differences. After bringing all the data of each question together, the researcher identified categories and themes and labeled them. Patterns and connections within and between categories were identified and used to understand and explain effects and relationship within and between themes. 


\section{Results and Discussion}

Findings of this study indicate that high crime rate in Site B is linked to a number of factors that attract or force individuals to pursue illegitimate activities. These factors include: poverty and high unemployment rate, bad social role model, lack of parental guidance, alcohol consumption and drug abuse, and ineffective criminal justice system.

\subsection{Poverty and high unemployment rate}

This study takes no exception to the existing findings of previous studies that linked crime to income distribution (Brown, 2001; Nleya \&Thompson, 2009). All participants of this study perceive poverty and unemployment as major root causes of crime in their community. The participants argued that many crimes are committed by poor and unemployed individuals who would be seeking food or money for food and other basic needs. One prominent participant from KDF referred most crimes committed in Site B and in other parts of Khayelitsha to 'crimes of needs'. The participant argued that the majority of Khayelitsha residents especially young people are poor and not working to earn income. In relation to this argument, findings of one study in 2006 show that more than half (65\%) of Khayelitsha residents were young people under 30 years old, and $52 \%$ of Khayelitsha residents were economically active but $28 \%$ of them are unemployed (City of Cape Town, 2006). Given this situation, individuals see committing crime as a strategy to make money so they can put food on the table.

\subsection{Alcohol consumption and drug abuse}

The consumption of alcohol and drug abuse are other factors that should not be neglected when investigating determinants of crime in townships and other poor communities in Cape Town. All interviewed people affirmed that the number of crimes committed under the influence of alcohol and drugs, as well as the number of drug abusers is noticeably increasing in Site B community. According to one of the interviewed street committee leaders, most of people who abuse drugs are young adults, and teenagers of whom some are still school learners. The most abused drug in the community is methamphetamine, which is commonly known as 'tik' in South Africa. In 2010, the same drug was also found to be among the most common primary substances of abuse in the Western Cape Province (Pluddemann, et al., 2010).

The majority of crimes related to alcohol consumption in Site B are committed during the week-ends because the majority of working people (those who are informally employed) get paid on week-end, normally on Friday or Saturday. As a result, they spend much of their weekend time in shebeens drinking². There are even some people who spend their week-ends in shebeens even if they have no money to spend as expressed by one participant:

During the week-end, people in townships want to enjoy themselves. It is the time for people especially young girls and men to show off. Even if they do not have money they dress up nicely and hang around shebeens and other public places such as shopping malls and markets.

In the interview at the Khayelitsha Police Station, another participant also corroborated the claim that the number of crimes reported at the police station as well as the high number of arrests is high during the weekends. The participant said:

If you want to confirm what I say, come to this station on Saturday or Sunday in the morning and see how many people who come to report crime cases. There are even those who spend a night here because they got arrested when are drunk or have committed crimes.

In many cases, crimes related to alcohol and drugs are committed by people who are looking for money to buy drugs and alcohol. The interviewed police officer commented that people commit crimes as long as they have no money to buy drugs or alcohol, and they have no alternative source of income. They rob people to get money for drugs or alcohol and when the money is spent, they go back looking for other potential crime victims to rob. The police officer referred this situation to as a 'viscous circle', committing crime to get money for drugs and alcohol over and over. However, there are also some incidences when drug abusers or alcohol consumers become crime victims. After losing control due to taking alcohol or drugs, they become crime targets. In 2007, it was found that more than 50\% of raped

2 In South Africa, shebeens are informal establishments or private houses (mostly unlicensed) that sell alcoholic drinks in townships. 
people in South Africa were high or drunk at the time of the incidents (Holtmann, 2008).

\subsection{Lack of proper parental guidance}

In many African traditional cultures, parents and other community members have responsibility for guiding and preventing children from pursuing non-conforming behaviours. Site B community however, seems to have lost this practice. Findings of this study indicate that most crimes in Site B are committed by teenagers and young adults. Consequently, parents are blamed for being reluctant to guide and control their children. Some parents are not even concerned or worried about where their children spend a day and what they do.

One participant disclosed that there are even some parents who support and protect their children when they commit crimes or fail to conform to shared values. The participant posited that when these parents are told that their children have involved in criminal activities, they aggressively defend their children. Although this participant had no concrete evidence, he suspects that those parents benefit from crimes committed by their children. This view was echoed by other participant from CPF who argued that most youth criminals are from single-headed families who struggle to put food on the table and to provide other basic needs for their children.

On the flipside, some parents have little or no time to guide and prevent their children from pursuing illegitimate activities as they spend much of their time at work leaving their children alone at home. Thus, parents may not be aware of all activities in which their children get involved. Leaving children alone at home often happens in townships (Palmary \& Moat, 2002). However, not all children left alone at home their parents are at work. There are other parents who spend their time in shebeens drinking. The police officer gave an example where children go missing and parents come to report the incident two to four hours later because they were in shebeens or were drunk the time of the incidence.

From parents' perspective, the South African government is to be blamed for spoiling children by forbidding parents to sanction their children. One parent claimed that children in post-apartheid South Africa are no longer listening and respecting their parents as it used to be in the past. She said that children are protected by laws and parents are not allowed to discipline their own children. If parents beat children they may get arrested by police. In this regard, the police officer condoned that parents can sanction their children but the problem is when sanctions given to children are excessive and harsh. If children are assaulted by their parents, the parents may face charges regardless whether the children were wrong or right. Police remain with no option other than enforcing laws when children are abused.

With this so-called protection, many children in Site B community have become intractable. Children claim that they have freedom and rights to do what they like and parents cannot stop them. In the interview, one young adult said that parents have no right to beat children anymore because they are in 'new' South Africa. He added that children in South Africa cannot be forced by their parents to do something they do not like. If they are forced, it is regarded as violation of their rights.

\subsection{Ineffective criminal justice system}

Consistent with finding of previous studies which indicate that the South African Criminal Justice is ineffective (Show, 1996; Brown, 2001; Singh, 2005, Faull, 2011), many participants blamed the criminal justice system, particularly the SAPS for failing to deter crime when its mandate include to prevent, combat and investigate crime, protect and secure citizens and their property, and enforce law (Republic of South Africa, 1996). Community members complain about delays by police to arrive at crime scene when they are called for help. Police arrive at crime scenes approximately 25 minutes after criminals have left.

In some instances, police are called for help when a person is in danger but the police give an excuse that they have no vehicles or there are no police officers available to send to the crime scene. The interviewed police officer and one Community Policing Forum (CPF) official affirmed the short of manpower to patrol all crime hot-spot areas. Undeniably, this shortage of resources affects service delivery in those police stations and has impacts crime situation in the township.

A large proportion of participants alleged that police are corrupt and some police officers get involved in criminal activities. The participants have no concrete evidence to support their allegations but existing literature shows that the allegations of corruption in the SAPS are common and stale in South Africa (Singh, 2005; Faull, 2011). The participants' allegations are based on numerous occasions in which police in Site B deliberately release crime suspects without any charges against them. One participant who used to volunteer in CPF patrolling streets in Site B gave a testimony where police released a crime suspect without charges: 
One night around $02 \mathrm{hO0}$ we were on duty patrolling, then we saw a person crossing from Mfuleni section to Khayelitsha. We stopped the person, he tried to run away but we caught him. He had a DVD player and cell phone. The person was locked in the police's vehicle, and then we continued to patrol. In the morning around 05h00, the police let the suspect go with the DVD player and cell phone. The police never even asked the suspect to prove whether the DVD player and cell phone belonged to him. They just let him go.

In relation to these allegations of corruption in the SAPS, the police officer appealed to the public to provide evidence when making allegations. However, she did not rule out that there could be some police officers who tarnish the image of the SAPS by getting involved in criminal activities including corruption. Arguably, corruption and release of crime suspects without acquitted by courts may motivate people to pursue criminal activities as they know that they may be released without being sanctioned. People are deterred from committing crimes by fear of punishment if they are caught (Fagan \& Meares, 2008).

\subsection{Bad social role models}

Social role models play an important part in transmitting and modifying individuals' behaviour. Individuals acquire new behaviour when they interact with or imitate behaviour of other people who they consider their role models in their society (Bandura, 1969; Krohn et al., 1985). Findings of this study show that Site B community is not an exception. People, particularly youth become criminals when they interact with criminals. One young adult who was a first year student at the University of the Western Cape at the time of the interview confessed that he became a gangster when he had started hanging around with his friends who were gangsters. Later on, he quit gangsterism after joining a local youth organisation where he got inspired to further his education. Youth in Site B are exposed to high level crime and interact with criminals on daily basis. Learning to become criminals or acquiring criminal behaviour, therefore, is not surprising.

\section{Conclusion}

Crime statistics and government officials indicate that crime rates are generally abating in the country but in some communities including Site B, Khayelitsha where this study was conducted, the crime situation is still unbearable. Residents of Site B community believe that crime rates are very high considering the high number of crimes committed each day. Crimes are committed anywhere and anytime in the community although the majority of crimes are committed during the weekends, and most of the offenders are young people of whom some are still teenagers.

Although a number of factors were identified as root causes of crime in Site B, residents believe that many crimes are linked to poverty and unemployment. The majority of Site B residents are unemployed and have no other source of income to sustain themselves and their families. Given this dire situation, pursuing criminal activities such as robbery or theft have, therefore, become avenues for some individual poor people in the community to make income. They commit crime to get money to buy food and other basic commodities

Poverty and high rate of unemployment rendered some residents into a hopeless situation. As a result, they indulge into alcohol consumption and drug abuse to relieve their stress. It is in such way that the number of crimes committed under the influence of drug abuse and alcohol consumption is perceived to be high and increasing in Site B. Crimes committed under the influence of alcohol and drugs to high crime rates in Site B come in twofold: crimes committed by people who will be looking for money to buy drugs or alcohol. On the other hand crimes are committed to drug abusers and alcohol consumers when lost their control after taking drugs or consuming alcohol.

\section{References}

Armstrong, P., Lekezwa, B., \& Siebrits, K. (2008). Poverty in South Africa: a profile based on recent household surveys. Stellenbosch Economic Working Papers 04/08. University of Stellenbosch.

Bandura, A. (1969). Social learning theory of identificatory process.[Online] available: http://des.emory.edu/mfp/bandura1969HSTR.pdf (March 13, 2011).

Berlinger, J. (2012). The 50 most dangerous city in the world. Business Insider, 9 October. [Online] Available: http://www.businessinsider.com /most-dangerous-cities-in-the-world-2012-10?op=1 (February 22, 2014].

Brown, K. V. (2001). The determinants of crime in South Africa. The South African Journal of Economics, 69(2), 269-299.

Burger, J. (2007). South Africa in 2020: an internal crisis, in L. Le Roux (Ed.), South African Army Vision 2020: Security Challenges Shaping the Future South African Army. Pretoria: Institute for Security Studies (ISS).

City of Cape Town (2006). Socio-economic profiling of urban renewal nodes - Khayelitsha and Mitchell's Plain. [Online] available: http://www.capetown.gov.za/en/stats/CityReports/Documents/Urban\%20Renewal\%20Programme/URP_Socio-Eco_Report_ 
228200612953_359.pdf (December 20, 2011].

City of Cape Town (2009). Khayelitsha urban upgrading programme launched. [Online] available: http://www.capetown.gov.za /en/Pages/Khayelitshaurbanupgradeprogrammelaunched.asp x (November 24, 2011).

Cozens, P. M., Saville, G., \& Hillier, D. (2005). Crime prevention through environmental design (CPTED): a review and modern bibliography. Property Management, 23(5), 328-356.

Cullen, J. B., \& Levitt, S. D. (1999). Crime, urban flight, and the consequences for cities. The Review of Economics and Statistics, 81(2), 159-169.

Cunliffe-Jones, P. (2013). A guide to crime statistics in South Africa: what you need to know. Africa Check. [Online] available: http://www.africacheck.org/reports/factsheet-crime-statistics-in-south-africa/ (October 31, 2013).

Demombynes, G., \& Özler, B. (2005). Crime and local inequality in South Africa. Journal of Development Economics, 76(2), $265-292$.

De Villiers, P., \& Nel, S. (2009). The opportunity cost of the upkeep of the criminal justice system in South Africa from 1980 to 2006. South African Journal of Economic and Management Sciences, 13(4), 407-423.

De Wet, C. (2003). Eastern Cape educators' perceptions of the causes and the scope of school violence. Acta Criminologica, 16(3), 89106.

Estelle, E. (2003). Poverty socker for Cape Town townships. [Online] available: http://www.101.co.za/news/south.africa/poverty-shockerfor-cape-townships-1,1150710 (June 25, 2013).

Fagan, J., \& Meares, T. L. (2008). Punishment, deterrence and social control: the paradox of punishment in minority communities. Yale Law School, Faculty Scholarship Series Paper 527. [Online] available: http://moritzlaw.osu.edu/osjcl/Articles/Volume6_1/FaganMeares-PDF.pdf (May 23, 2011).

Faull, A. (2007). Corruption and the South African Police Service: a review and its implications. Institute for Security Studies (ISS) Paper 150. September 2007.

Faull, A. (2011). Corruption in the South African Police Service: civilian perceptions and experience. Institute for Security Studies (ISS), Paper 226. November 2011.

Frank, C. (2006). Abuse of a different kind - adults using children to commit crime. South African Crime Quarterly, 16, 13-18.

Gie, J. (2009). Crime in Cape Town: 2001 - 2008 a brief analysis of reported violent, property and drug-related crime in Cape Town. Strategic Development Information and GIS Department, City of Cape Town.

Global Peace Index (GPI) (2013). Measuring the state of global peace. [Online] available: http://www.visionofhumanity.org /pdf/gpi/2013_Global_Peace_Index_Report.pdf (March 24, 2014).

Guarte, J. M., \& Barrios, E. B. (2006). Estimation under purposive sampling. Communications in Statistics Simulation and Computation, 35(2), 277-284.

Holtmann, B. (2008). Why law enforcement is not enough - lessons from the Central Karoo on breaking the cycle of crime and violence. South African Crime Quarterly, 23, 13-20

Ikejiaku, B. V. (2009). 'Crime', poverty, political corruption and conflict in apartheid and post-apartheid South Africa: the implications on economic development. African Journal of Political Science and International Relations, 3(10), 451-459.

Institute of Security Studies (2012). Facts sheet: explaining official crime statistics for 2012/2013. [Online] available: http://www.issafrica.org/crimehub/uploads/Explaining-the-official-crime-statistics-for-2012-13-factsheet.pdf. (June 23, 2013).

Kagee, H., \& Frank, C. (2005). COAV cities project - rapid assessment for Cape Town. Institute for Security Studies, 1-25. December 2005.

Krohn, M. D., Skinner, W. F., Massey, J. L., \& Akers, R. L. (1985). Social learning and adolescent cigarette smoking: a longitudinal study. Social Problems, 32(5), 455-473.

Legg, K. (2013). SA's most violent neighbourhoos. IOL news, 20 September. [Online] Available: http://www.iol.co.za/news/crimecourts/sa-s-most-violent-neighbourhoods-1.1580294. (February 22, 2014).

Manaliyo, J. C. (2012). Local solutions from local people: community participation in crime prevention in Khayelitsha. Unpublished MA thesis, University of the Western Cape.

Manaliyo, J. C., \& Muzindutsi, P. F. (2003). Community participation in crime prevention: informal social control practices in Site B, Khayelitsha township. Mediterranean Journal of Social Sciences, 4(3), 121-127.

Møller, V. (2005). Resilient or resigned? Criminal victimization and quality of life in South Africa. Social Indicators Research, 72(3), 263317.

Muhammad, A. (2008). Youth crime: causes and remedies. Munich Personal RePEc Archive (MPRA), June 2008. [Online] available: http://mpra.ub.uni-muenchen.de/17223/1/MPRA_paper_17223.pdf (September 24, 2011).

Newham, G. (2005). A decade of crime prevention in South Africa: from a national strategy to a local challenge. Centre for the Study of Violence and Reconciliation (CSVR). [Online] available: http://www.csvr.org.za/docs/crime/decadeofcrime.pdf (March 21, 2011).

Nleya, N., \& Thompson, L. (2009). Survey methodology in violence - prone Khayelitsha, Cape Town, South Africa. IDS (Institute of Development Studies) Bulletin, 40(3), 50-57.

OECD (2008). OECD Territorial Reviews: Cape Town, South Africa. OECD Publishing. [Online: available: http://books.google.co.za /books?id=NSAobDAatbMC\&pg=PA198\&dq=khayelitsha+most+dangerous+area+in+south+africa\&hl=en\&sa=X\&ei=LiEoU96nMl O07Qb6pYCwCw\&ved=0CCcQ6AEwAg\#v=onepage\&q=khayelitsha\%20most\%20dangerous\%20area\%20in\%20south\%20africa \&f=false. (March 13, 2013).

Omar, B. (2004). Crime and safety in South Africa: release of the 2003 national victim survey results. [Online] available: http://www.iss.org.za/media/SANVCSeminar02_03_04.htm. (February 19, 2011). 
Palmary, I. (2001). Social crime prevention in South Africa's major cities. Centre for the Study of Violence and Reconciliation (CSVR), June 2011.

Palmary, I., \& Moat, C. (2002). Preventing criminality among young people. Centre for the Study of Violence and reconciliation (CSVR), December 2002. [Online] available: http://www.csvr.org.za/docs/crime/preventingcriminality.pdf (March 12, 2012).

Paulse, J., \& Lazarus, S. (2010). Colonisation, apartheid and historical trauma as risks for male violence: report on proceedings of symposium. African Safety Promotion Journal, 8(1), 51-63.

Pelser, E. (2008). Learning to be lost: youth clime in South Africa. Discussion Paper for the HSCD Youth Policy Initiative, Reserve Bank, Pretoria. May 13, 2008.

Pluddemann, A., Dada, S., Parry, C., Bhana, A., Bachoo, S., Perreira, T., Nel, E., Mncwabe, Gerber, W., \& Freytag, K. (2010). Monitoring alcohol and drug abuse trends in South Africa (July 1996-June 2010). SACENDU Research Brief, 13(2), 1-15.

Ratele, K. (2010). Young black males at risk of homicidal violence. South Africa Crime Quarterly, (33), 19-24.

Republic of South Africa (1996). Constitution of the Republic of South Africa No. 108 of 1996. [Online] available: http://www.info.gov.za/documents/constitution/1996/a108-96.pdf. (October 25, 2013).

Republic of South Africa (1998). White Paper on Safety and Security. [Online] available: http://www.info.gov.za/whitepapers /1998/safety.htm\#drafting (July 30, 2011).

Republic of South Africa (2008). The impact of crime on small businesses in South Africa. [Online] available: http://www.info.gov.za/view /DownloadFileAction?id=85235 (May 20, 2011).

Republic of South Africa (2013). HIS Index confirms crime statistics - Mthetwa. South African Government News Agency. [Online] available: http://www.sanews.gov.za/south-africa/ihs-index-confirms-crime-statistics-mthethwa. (October 31, 2013).

Sampson, R. J. \& Groves, W. B. (1989). Community structure and crime: testing social disorganisation theory. American Journal of Sociology, 94(4), 774-802.

Schönteich, M. (1999). Assessing the crime fighters: the ability of the criminal justice system to solve and prosecute crime. Institute for Security Studies (ISS), Occasional Paper No. 40, September 1999. [Online] available: http://www.iss.org.za/uploads/paper40.pdf. (July, 25, 2011).

Shaw, M. (1996). Reforming South Africa's criminal justice system. Institution for Security Studies (ISS), Occasional Paper, No. 8. August 1996.

Shaw, M. (1997). South Africa: crime in transition. Institution for Security Studies (ISS), Occasional paper No. 17, March 1997.

Shaw, M. (2002). Crime and Policing in Post-apartheid South Africa: Transforming Under Fire. New African Books (Pty) Ltd, Cape Town.

Shaw, M. \& Louw, A. (1997). The violence of alcohol: crime in Northern Cape. [Online] available: http://www.crimeinstitute.ac.za /reports/facric.pdf (January 11, 2011).

Sigh, D. (2005). Restoring to community justice when state policing fails South Africa. Acta Criminologica, 18(3), 43-50.

Silber, G., \& Geffen, N. (2009). Race, Class, and Violent crime in South Africa: dispelling the 'Huntley thesis'. SA Crime Quarterly, (30), $35-43$.

South Africa Medical Research Centre (SAMRC) and University of South Africa (UNISA) (2004). A profile of fatal injuries in South Africa. 6th Annual Report of the National Injury Mortality Surveillance System 2004. [Online] available: http://www.sahealthinfo.org/violence/national2004.pdf. (March 14, 2012).

South African Council for Education (SACE) (2011). School-based violence report, an overview of school-based violence in South Africa [Online] available: http://www.sace.org.za/upload/files/School\%20Based\%20Violence\%20Report-2011.pdf. (February 19, 2014).

South African Police Service (2002). National Crime Combating Strategy. [Online] available: http://www.saps.gov.za/saps_profile /strategic framework/strategic plan/2002 2005/strategic plan5.htm. (August 3, 2011).

South African Police Service (2011). Information on predetermined objectives. Annual Report 2010/2011.[Online] available: http://www.saps.gov.za/statistics/reports/crimestats/2011/crime_stats.htm. (December 23, 2011).

Statistics South Africa (2012). Victims of crime survey. [Online] available: http://www.statssa.gov.za/publications/P0341/P03412012.pdf. (March 18, 2013).

Stone, C. (2006). Crime, justice, and growth in South Africa: toward a plausive contribution from criminal justice to economic growth. CID Working Paper No. 131, August 2006. [Online] available: http://www.hks.harvard.edu/var/ezp_site/storage/fckeditor/file/pdfs /centers- programs/ceners/cid/publications/faculty/wp/131.pdf. (March 23, 2011).

Tongoco, M. D. C. (2007). Purposive sampling as tool for informant selection. Ethnobotany Research and Applications, 5, 147-158.

University of Stellenbosch (2011). Facts sheet. The BOP Learning Lab. [Online] available: http://www.bop.org.za/BOP_Lab /Publications files/Khayelitsha11.pdf. (March 15, 2014)

Weijters, G., Scheepers, P., \& Gerris, J. (2009). City/or neighbourhood determinants? Studying contextual effects on youth delinquency. European Journal of Criminology, 6(5), 439-555. 